\title{
COMPUTER SIMULATION FOR HYDROGEN PRODUCTION FROM THE STEAM REFORMING OF METHANE
}

\author{
A. A. N. OLIVEIRA ${ }^{1}$ AND J. D. SILVA ${ }^{2 *}$ \\ ${ }^{1,2}$ Polytechnic School - UPE, Laboratory of Environmental and Energetic Technology; Rua \\ Benfica - 455, Madalena, Recife - PE, Brazil, Cep: 50750-470, phone: (81) 3183-7515, \\ Corresponding author, E-mail address: *jornandesdias@poli.br
}

\begin{abstract}
This paper presents an one-dimensional isothermal modelling for a CFBMR $\left(\mathrm{H}_{2}\right.$ permeable). The work has been developed to simulate the SRM to produce $\mathrm{H}_{2}$. The dynamic simulation for molar flow rates of $\mathrm{H}_{2}$ was analyzed in the permeation side and shell side zones at different temperatures at the exit of the proposed system. The model has allowed the validation for the conversion of $\mathrm{CH}_{4}$ by comparing of optimized values. Additionally, the molar flow rates for chemical species $\mathrm{CH}_{4}, \mathrm{H}_{2} \mathrm{O}, \mathrm{H}_{2}, \mathrm{CO}$ and $\mathrm{CO}_{2}$ were analyzed along of the CFBMR (permeation side and shell side) at different times.
\end{abstract}

\section{INTRODUCTION}

The steam reforming of methane (SRM) is the primary hydrogen production route on industrial scale. Methane $\left(\mathrm{CH}_{4}\right)$ is the main component of conventional natural gas (NG) which can also be obtained from associated gas, stranded NG and shale gas. It was previously determined that three reactions are predominant (Xu and Froment, 1989), the (SRM), water gas shift (WGS) and overall steam reforming of methane (OSRM).

- Reaction of the SRM;

$$
\mathrm{CH}_{4}+\mathrm{H}_{2} \mathrm{O} \leftrightarrow \mathrm{CO}+3 \mathrm{H}_{2} ; \Delta \mathrm{H}_{298 \mathrm{~K}}^{0}=205.8 \mathrm{~kJ} \mathrm{~mol}^{-1}
$$

- Reaction of the WGS;

$$
\mathrm{CO}+\mathrm{H}_{2} \mathrm{O} \leftrightarrow \mathrm{CO}_{2}+\mathrm{H}_{2} ; \Delta \mathrm{H}_{298 \mathrm{~K}}^{0}=-41.1 \mathrm{~kJ} \mathrm{~mol}^{-1}
$$

- Reaction of the OSRM.

$$
\mathrm{CH}_{4}+2 \mathrm{H}_{2} \mathrm{O} \leftrightarrow \mathrm{CO}_{2}+4 \mathrm{H}_{2} ; \Delta \mathrm{H}_{298 \mathrm{~K}}^{0}=164.9 \mathrm{~kJ} \mathrm{~mol}^{-1}
$$

The steam reforming process of methane (SRPM) for the hydrogen production can be studied using various reactor configurations such as fixed be reactors, fluidized bed reactors and membrane reactors (fixed bed membrane reactors or fluidized bed membrane reactors). The use of a permeable membrane reactor offers the potential for a compact unit in combining both the reaction and separation in a simple unit. Several studies have been carried out over SRPM for separating $\mathrm{H}_{2}$ from a reaction mixture using Pd-based membrane reactors. The most of these researches have been experimentally and numerically investigated to produce $\mathrm{H}_{2}$ at high temperature. The main focus of the experimental studies was to develop the robust catalysts which are resistant to carbon deposition. On 


\section{9 a 22 de outubro de 2014 \\ Florianópolis/SC}

the other hand, the numerical works have been reported to simulate the hydrogen production using Pd-based membrane and robust catalysts, respectively.

The catalytic fixed bed membrane reactors (CFBMRs) can significantly improve the production of thermodynamically limited reactions. Hydrogen-selective membranes permit hydrogen produced by reactions to escape under the influence of the difference in the hydrogen partial pressures to the permeate side where an inert gas such as nitrogen can be used to purge hydrogen. This type reactor is promising for thermodynamically limited reactions such as steam reforming. In this CFBMRs, the effect of the intraphase transport by considering diffusion inside the catalyst pellets on both sides of the coupled CFBMR.

The commercial hydrogen separation by metallic membranes is mainly focused on palladium alloys. Palladium (Pd) membranes have been proposed for application in hydrogen separation for many years due to their exclusive selectivity for hydrogen. Pd is known to be highly soluble for hydrogen and it can tolerate hydrocarbon containing streams. Pd-based membranes also put forward the possibility of hydrogen separation at high temperature aiming at combining a separation process with a chemical reaction in one unit.

The most of the mathematical models (CFBMRs) of the literature are investigated in steady-state operation (Abashar, 2013, Keyur and Aydin, 2007). Our main contribution to the prediction of SRM in CFBMR is develop an original model which includes the dynamic modelling by predicting the behaviour of a real unit. Another important contribution made in the present paper is to use the numerical Laplace transform to obtain an efficient solution with fast convergence and minimization of the numeral error.

\section{MATERIALS AND METHODS}

A conceptual schematic of the integrated CFBMR was developed to investigate the SRM according to the Figure 1.

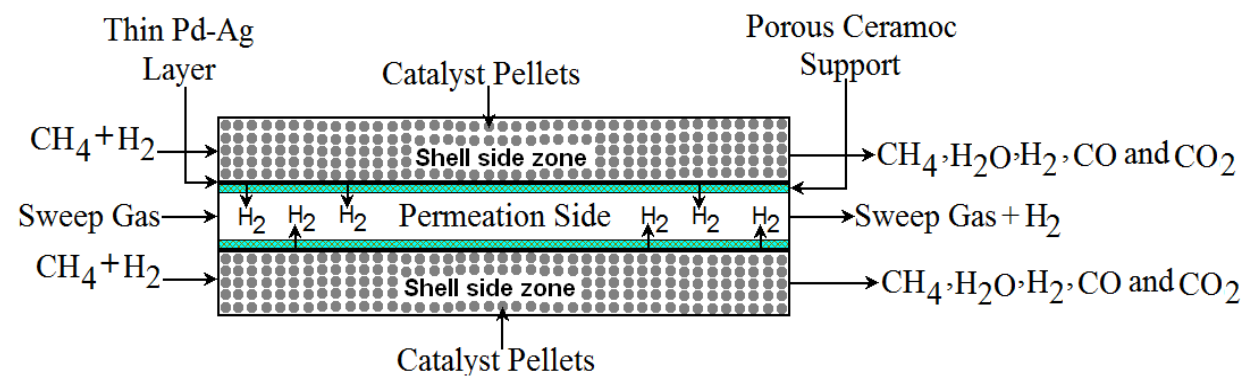

Figure 1 Schematic representation of the CFBMR for the SRM.

The inner is the tube is the supported membrane and the outer one is the non-permeable shell. The catalyst $\left(\mathrm{Ni} / \gamma-\mathrm{Al}_{2} \mathrm{O}_{3}\right)$ is packed in the shell side where the reactants (methane and steam) are introduced. The sweep gas (nitrogen or steam) is fed into the tube side in the co-current flow mode. In this system, three reforming reactions occur in the non-permeable shell by producing light gases $\left(\mathrm{H}_{2}, \mathrm{CO}\right.$ and $\left.\mathrm{CO}_{2}\right)$. 


\subsection{Kinetic Mechanism}

The process discussed here has involved the main reactions of SRM. In normal operation, the reaction (1) is the SRM, the reaction (2) shows water-gas shift and the reaction (3) presents the overall SRM. Reactions (1), (2) and (3) are reversible (equilibrium). Thermodynamically, reactions (1) and (3) are strongly endothermic. On the other hand, the reaction (2) is exothermic. Components of reactions (1), (2) and (3) are defined like methane $\left(\mathrm{CH}_{4}\right)$, water $\left(\mathrm{H}_{2} \mathrm{O}\right)$, carbon monoxide $(\mathrm{CO})$, hydrogen $\left(\mathrm{H}_{2}\right)$ and carbon dioxide $\left(\mathrm{CO}_{2}\right)$. The stoichiometric coefficients of components were presented in Table 1.

Table 1: Stoichiometric coefficients $\sigma_{\mathrm{ij}}$ for components of reactions

\begin{tabular}{|c|c|c|c|c|c|}
\hline Reactions & $\mathrm{CH}_{4}$ & $\mathrm{H}_{2} \mathrm{O}$ & $\mathrm{CO}$ & $\mathrm{H}_{2}$ & $\mathrm{CO}_{2}$ \\
\hline 1 & -1 & -1 & +1 & +3 & 0 \\
\hline 2 & 0 & -1 & -1 & +1 & +1 \\
\hline 3 & -1 & -2 & 0 & +4 & +1 \\
\hline
\end{tabular}

\subsection{Kinetic Modelling}

The kinetic mathematical model applied here considers only three homogeneous reactions (1), (2) and (3) according to Langmuir-Hinshelwood concept (Xu and Froment, 1989).

$$
\begin{aligned}
\mathrm{R}_{1}=\frac{\mathrm{k}_{1}}{\mathrm{P}_{\mathrm{H}_{2}}^{2.5}} \frac{\left(\mathrm{P}_{\mathrm{CH}_{4}} \mathrm{P}_{\mathrm{H}_{2} \mathrm{O}}-\frac{\mathrm{P}_{\mathrm{H}_{2}}^{3} \mathrm{P}_{\mathrm{CO}}}{\mathrm{K}_{\mathrm{eq}, 1}}\right)}{\left(1+\mathrm{K}_{\mathrm{CO}} \mathrm{P}_{\mathrm{CO}}+\mathrm{K}_{\mathrm{H}_{2}} \mathrm{P}_{\mathrm{H}_{2}}+\mathrm{K}_{\mathrm{CH}_{4}} \mathrm{P}_{\mathrm{CH}_{4}}+\frac{\mathrm{K}_{\mathrm{H}_{2} \mathrm{O}} \mathrm{P}_{\mathrm{H}_{2} \mathrm{O}}}{\mathrm{P}_{\mathrm{H}_{2}}}\right)^{2}} \\
\mathrm{R}_{2}=\frac{\mathrm{k}_{2}}{\mathrm{P}_{\mathrm{H}_{2}}} \frac{\left(\mathrm{P}_{\mathrm{CO}} \mathrm{P}_{\mathrm{H}_{2} \mathrm{O}}-\frac{\mathrm{P}_{\mathrm{H}_{2}} \mathrm{P}_{\mathrm{CO}_{2}}}{\mathrm{~K}_{\mathrm{eq}, 2}}\right)}{\left(1+\mathrm{K}_{\mathrm{CO}} \mathrm{P}_{\mathrm{CO}}+\mathrm{K}_{\mathrm{H}_{2}} \mathrm{P}_{\mathrm{H}_{2}}+\mathrm{K}_{\mathrm{CH}_{4}} \mathrm{P}_{\mathrm{CH}_{4}}+\frac{\mathrm{K}_{\mathrm{H}_{2} \mathrm{O}} \mathrm{P}_{\mathrm{H}_{2} \mathrm{O}}}{\mathrm{P}_{\mathrm{H}_{2}}}\right)^{2}} \\
\mathrm{R}_{3}=\frac{\mathrm{k}_{3}}{\mathrm{P}_{\mathrm{H}_{2}}^{3.5}} \frac{\left.\mathrm{P}_{\mathrm{CH}_{4}} \mathrm{P}_{\mathrm{H}_{2} \mathrm{O}}^{2}-\frac{\mathrm{P}_{\mathrm{H}_{2}}^{4} \mathrm{P}_{\mathrm{CO}_{2}}}{\mathrm{~K}_{\mathrm{eq}, 3}}\right)}{\left(1+\mathrm{K}_{\mathrm{CO}} \mathrm{P}_{\mathrm{CO}}+\mathrm{K}_{\mathrm{H}_{2}} \mathrm{P}_{\mathrm{H}_{2}}+\mathrm{K}_{\mathrm{CH}_{4}} \mathrm{P}_{\mathrm{CH}_{4}}+\frac{\mathrm{K}_{\mathrm{H}_{2} \mathrm{O}} \mathrm{P}_{\mathrm{H}_{2} \mathrm{O}}}{\mathrm{P}_{\mathrm{H}_{2}}}\right)^{2}}
\end{aligned}
$$

The reaction rate coefficients $\left(\mathrm{k}_{\mathrm{j}}, \mathrm{j}=\mathrm{SRM}\right.$, WGS and OSRM) and the adsorption constants of gases $\left(\mathrm{K}_{\mathrm{CH}_{4}}, \mathrm{~K}_{\mathrm{H}_{2} \mathrm{O}}, \mathrm{K}_{\mathrm{H}_{2}}\right.$ and $\left.\mathrm{K}_{\mathrm{CO}}\right)$ have an Arrhenius type dependence with temperature. On the other hand, $\mathrm{P}_{\mathrm{i}}\left(\mathrm{i}=\mathrm{CH}_{4}, \mathrm{H}_{2} \mathrm{O}, \mathrm{CO}, \mathrm{H}_{2}\right.$ and $\left.\mathrm{CO}_{2}\right)$ are the partial pressures of the respective 
components within the catalyst. The Arrhenius expressions for the reaction rate coefficients, adsorption constants for the components $\mathrm{CH}_{4}, \mathrm{H}_{2} \mathrm{O}, \mathrm{H}_{2}$ and $\mathrm{CO}$ and the equilibrium constants are listed in the Table 2.

Table 2: Kinetic, adsorption and equilibrium parameters for the reactions involved in steam reforming process of methane (Xu and Froment, 1989)

\begin{tabular}{|l|l|}
\hline Rate coefficients, Equations (4) to (6) & Units \\
\hline $\mathrm{k}_{1}=9.490 \times 10^{16} \exp \left(-\frac{28.879 \mathrm{~K}}{\mathrm{~T}_{\mathrm{s}}}\right) ; \mathrm{k}_{2}=4.390 \times 10^{4} \exp \left(-\frac{8074.3 \mathrm{~K}}{\mathrm{~T}_{\mathrm{s}}}\right)$ & $\mathrm{kmolkP}_{\mathrm{a}}^{0.5} \mathrm{~kg}^{-1} \mathrm{~h}^{-1}$ \\
\hline Adsorption coefficient constants & $\mathrm{kmol} \mathrm{kP}_{\mathrm{a}}^{-1} \mathrm{~kg}^{-1} \mathrm{~h}^{-1}$ \\
$\mathrm{~K}_{\mathrm{CH}_{4}}=6.650 \times 10^{-4} \exp \left(\frac{4604.20 \mathrm{~K}}{\mathrm{~T}_{\mathrm{s}}}\right) ; \mathrm{K}_{\mathrm{H}_{2} \mathrm{O}}=1.770 \times 10^{3} \exp \left(-\frac{10666.35 \mathrm{~K}}{\mathrm{~T}_{\mathrm{s}}}\right)$ & $\mathrm{kP}_{\mathrm{a}}^{-1}$ \\
$\mathrm{~K}_{\mathrm{H}_{2}}=6.120 \times 10^{-11} \exp \left(\frac{9971.13 \mathrm{~K}}{\mathrm{~T}_{\mathrm{s}}}\right) ; \mathrm{K}_{\mathrm{CO}}=8.230 \times 10^{-7} \exp \left(\frac{8497.71 \mathrm{~K}}{\mathrm{~T}_{\mathrm{s}}}\right)$ & $\mathrm{kP}_{\mathrm{a}}^{-1}$ \\
\hline $\mathrm{K}_{\mathrm{eq}, 1}=10266.76 \exp \left(-\frac{26.336 \mathrm{~K}}{\mathrm{~T}_{\mathrm{s}}}\right)$ & \\
$\mathrm{K}_{\mathrm{eq}, 3}=\left\{10266.76 \exp \left(-\frac{26.830 \mathrm{~K}}{\mathrm{~T}_{\mathrm{s}}}+30.11\right) \exp \left(\frac{4400 \mathrm{~K}}{\mathrm{~T}}-4.063\right)\right\}$ & $\mathrm{T}_{\mathrm{s}}^{2}$ \\
\hline
\end{tabular}

The net rates for each component (consumption and formation) type of reactions (1), (2) and (3) have been obtained by using the following equation (Oliveira and Silva, 2012).

$$
r_{i}=\sum_{j=1}^{n} \sigma_{i j} R_{j}
$$

Where $r_{i}$ are the net rates of that species (i) in reactions $\left(R_{j}\right), \sigma_{i j}$ are the stoichiometric coefficients of species and $R_{j}$ are the reaction (1), (2) and (3) rates.

The effectiveness factors $\left(\eta_{i}\right)$ are used to account for the intraparticle transport limitation. Thus, the Equation (6) was rewritten as given below.

$$
\mathrm{r}_{\mathrm{i}}=\sum_{\mathrm{j}=1}^{\mathrm{n}} \eta_{\mathrm{j}} \sigma_{\mathrm{ij}} \mathrm{R}_{\mathrm{j}}
$$

The Equation (8) can be used to obtain $\mathrm{r}_{\mathrm{CH}_{4}}, \mathrm{r}_{\mathrm{H}_{2} \mathrm{O}}, \mathrm{r}_{\mathrm{H}_{2}}, \mathrm{r}_{\mathrm{CO}}$ and $\mathrm{r}_{\mathrm{CO}_{2}}$. The details of these net rates have given by Oliveira and Silva (2012). 


\section{MATHEMATICAL MODELLING}

The mathematical modelling and computer simulation for the CFBMR are in continuous development aiming to improve the knowledge of the phenomenological processes for this simple unit (combining both the reaction and separation). For this work, an one-dimensional mathematical model without axial dispersion taking into account diffusional limitations in the solid porous network was developed. This model has been projected like isothermal dynamic pseudo-homogeneous model.

\subsection{Balance Equations for the Shell Side}

The differential balances of the molar flow rates $\left(\mathrm{F}_{\mathrm{i}}\right)$ for the model components $\mathrm{i}\left(\mathrm{i}=\mathrm{CH}_{4}\right.$, $\mathrm{H}_{2} \mathrm{O}, \mathrm{H}_{2}, \mathrm{CO}$ and $\mathrm{CO}_{2}$ ) in the reaction side (shell side) are given as follows.

$$
\frac{\mathrm{u}_{\mathrm{s}}}{\mathrm{g}} \frac{\partial \mathrm{F}_{\mathrm{i}}}{\partial \mathrm{t}}+\frac{4 \tau \mathrm{Q}_{\mathrm{g}}}{4 \mathrm{~d}_{\text {shell }}^{2}} \frac{\partial \mathrm{F}_{\mathrm{i}}}{\partial \mathrm{z}}=\pi \mathrm{R}_{\text {Shell }}^{2} \rho_{\mathrm{s}} \mathrm{L}\left(1-\varepsilon_{\mathrm{b}}\right) \sum_{\mathrm{j}=1}^{3} \eta_{\mathrm{j}} \sigma_{\mathrm{ij}} \mathrm{R}_{\mathrm{j}}-2 \pi \mathrm{R}_{\text {Shell }} \mathrm{J}_{\mathrm{i}}^{\mathrm{s}} \text {; when } \mathrm{i} \neq \mathrm{H}_{2} \text {, thus } \mathrm{J}_{\mathrm{i} \neq \mathrm{H}_{2}}^{\mathrm{s}}=0
$$

- The initial and boundary conditions for the Equation (8) are given as:

$\left.\mathrm{F}_{\mathrm{i}}\right|_{\mathrm{t}=0}=\mathrm{F}_{\mathrm{i}, 0} ;$ for all $\mathrm{z} ;\left.\mathrm{F}_{\mathrm{i}}\right|_{\mathrm{t}=0}=\mathrm{F}_{\mathrm{i}, 0}$ for reac $\tan \mathrm{ts}$ and $\left.\mathrm{F}_{\mathrm{i}}\right|_{\mathrm{t}=0}=0$ for products

$\left.\mathrm{F}_{\mathrm{i}}\right|_{\mathrm{z}=0^{+}}=\mathrm{F}_{\mathrm{i} \text {,Ent. }} ;$ for $\mathrm{t} \geq 0$

$$
\left.\frac{\partial \mathrm{F}_{\mathrm{i}}}{\partial \mathrm{z}}\right|_{\mathrm{z}=\mathrm{L}}=0 ; \text { for } \mathrm{t} \geq 0
$$

\subsection{Balance Equation for the Permeation Side}

The mass balance equation for the molar flow rate $\left(\mathrm{F}_{\mathrm{H} 2}\right)$ of $\mathrm{H}_{2}$ in the permeation side zone (inner tube of CFBMR) is written as follows:

$$
\frac{\mathrm{u}_{\mathrm{s}}}{\mathrm{g}} \frac{\partial \mathrm{F}_{\mathrm{H}_{2}}}{\partial \mathrm{t}}+\frac{4 \tau \mathrm{Q}_{\mathrm{g}}}{4 \mathrm{~d}_{\text {inner tube }}^{2}} \frac{\partial \mathrm{F}_{\mathrm{H}_{2}}}{\partial \mathrm{z}}=1.0061 \times 10^{-12} \exp \left(-\frac{767.38}{\mathrm{~T}}\right)\left(\frac{\mathrm{A}}{\delta}\right)\left[\left(\mathrm{P}_{\mathrm{H}_{2}}^{\mathrm{s}}\right)^{0.5}-\left(\mathrm{P}_{\mathrm{H}_{2}}^{\mathrm{t}}\right)^{0.5}\right]
$$

- The initial and boundary conditions for the Equation (11) are given as:

$$
\begin{aligned}
& \left.\mathrm{F}_{\mathrm{H}_{2}}\right|_{\mathrm{t}=0}=0 \text {; for all } \mathrm{z} \\
& \left.\mathrm{F}_{\mathrm{H}_{2}}\right|_{\mathrm{z}=0^{+}}=\mathrm{F}_{\mathrm{H}_{2}, \text { Ent. }} \text {; for } \mathrm{t} \geq 0 \\
& \left.\frac{\partial \mathrm{F}_{\mathrm{H}_{2}}}{\partial \mathrm{z}}\right|_{\mathrm{z}=\mathrm{L}}=0 \text {; for } \mathrm{t} \geq 0
\end{aligned}
$$




\section{SOLUTION OF THE MODEL EQUATIONS USING THE TECHNIQUE OF THE LAPLACE TRANSFORM}

The Laplace transform methodology was applied for changing the set of the partial differential equations (PDFs) into a set of ordinary differential equations (EDOs). Then, the new set of EDOs has been integrated by a subroutine based on the Runge-Kutta Gill with automatic step size and double precision to ensure accuracy (Silva and Oliveira, 2013).

\section{RESULTS AND DISCUSSIONS}

The mathematical modelling was developed to analyze the molar flow rates of chemical species $\left(\mathrm{CH}_{4}, \mathrm{H}_{2} \mathrm{O}, \mathrm{H}_{2}, \mathrm{CO}\right.$ and $\left.\mathrm{CO}_{2}\right)$ on the shell side zone as well as the molar flow rate of $\mathrm{H}_{2}$ into the permeation side zone. The proposed model for this work has been used to relate the evolution of the molar flow rates over space (z) along the CFBMR (shell side zone and permeation side zone). For this simulation, the computational code was fed with parameters shown in the Table 3.

Table 3: Parameters for the modelling involved in steam reforming of methane

\begin{tabular}{|c|c|c|c|}
\hline Categories & Properties & Nu. values & References \\
\hline \multirow[t]{4}{*}{ Operating conds. } & Shell side feed inlet temp., $\mathrm{T}_{\mathrm{in}, \mathrm{ss}}(\mathrm{K})$ & 800 & Ji et al., (2003) \\
\hline & Per. side feed inlet temp., $\mathrm{T}_{\mathrm{in}, \mathrm{ps}}(\mathrm{K})$ & 800 & Ji et al., (2003) \\
\hline & Shell side pressure $\mathrm{P}_{\mathrm{ss}}$, (bar) & 14 & Ji et al., (2003) \\
\hline & Permeation side pressure, (bar) & 14 & Ji et al., (2003) \\
\hline \multirow[t]{11}{*}{ Feed composit. } & Inlet flow rate of $\mathrm{CH}_{4}, \mathrm{~F}_{\mathrm{CH} 4}\left(\mathrm{kmol} \mathrm{s}^{-1}\right)$ & $2.5 \times 10^{-6}$ & Ji et al., (2003) \\
\hline & Inlet flow rate of $\mathrm{H}_{2} \mathrm{O}, \mathrm{F}_{\mathrm{H} 2 \mathrm{O}}\left(\mathrm{kmol} \mathrm{s}^{-1}\right)$ & $3.5 \times 10^{-6}$ & Ji et al., (2003) \\
\hline & Inlet flow rate of $\mathrm{H}_{2}, \mathrm{~F}_{\mathrm{H} 2}\left(\mathrm{kmol} \mathrm{s}^{-1}\right)$ & 0 & Ji et al., (2003) \\
\hline & Inlet flow rate of $\mathrm{CO}, \mathrm{F}_{\mathrm{CO}}\left(\mathrm{kmol} \mathrm{s}^{-1}\right)$ & 0 & Ji et al., (2003) \\
\hline & Inlet flow rate of $\mathrm{CO}_{2}, \mathrm{~F}_{\mathrm{CO} 2}\left(\mathrm{kmol} \mathrm{s}^{-1}\right)$ & 0 & Ji et al., (2003) \\
\hline & $\mathrm{CH}_{4} / \mathrm{H}_{2} \mathrm{O}$ ratio & 0.667 & Ji et al., (2003) \\
\hline & Inlet partial pres. of $\mathrm{CH}_{4}, \mathrm{p}_{\mathrm{CH} 4}$ (bar) & 5.46 & Pantoleontos et al.,(2012) \\
\hline & Inlet partial pres. of $\mathrm{H}_{2} \mathrm{O}, \mathrm{p}_{\mathrm{H} 2 \mathrm{O}}$ (bar) & 18.34 & Pantoleontos et al.,(2012) \\
\hline & Inlet partial pres. of $\mathrm{H}_{2}, \mathrm{p}_{\mathrm{H} 2}$ (bar) & 0.68 & Pantoleontos et al.,(2012) \\
\hline & Inlet partial pres. of $\mathrm{CO}, \mathrm{p}_{\mathrm{co}}$ (bar) & 0.00 & Pantoleontos et al.,(2012) \\
\hline & Inlet partial pres. of $\mathrm{CO}_{2}, \mathrm{p}_{\mathrm{CO} 2}$ (bar) & 0.31 & Pantoleontos et al.,(2012) \\
\hline \multirow[t]{5}{*}{ Gas solid } & Porosity of catalyst bed, $\varepsilon_{\mathrm{b}}$ (dimen.) & 0.43 & Ji et al., (2003) \\
\hline & Catalyst density, $\rho_{\mathrm{B}}\left(\mathrm{kg} \mathrm{m}^{-3}\right)$ & 2100 & Ji et al., (2003) \\
\hline & Effect. Factors $\left(\eta_{\mathrm{i}}\right)$ for Eqs. 1, 2, 3 & $0.07,0.07,0.57$ & $\mathrm{Xu}$ and Froment, (1989) \\
\hline & Shell side radius, $\mathrm{R}_{\text {shell }}(\mathrm{m})$ & $3.00 \times 10^{-3}$ & Ji et al., (2003) \\
\hline & Thickness of dense membrane, $\delta(\mathrm{m})$ & $5.0 \times 10^{-5}$ & Ji et al., (2003) \\
\hline
\end{tabular}

Figure (2a) shows a validation before simulating the CFBMR, the main program which is used to simulate the conventional CFBMR has been checked with data of the literature. The simulation results for conversion of $\mathrm{CH}_{4}$ and data for different authors were validated by 
comparison (Tong and Matsumura, 2006). Figure (2b) reports the profiles of $\mathrm{CH}_{4}, \mathrm{H}_{2} \mathrm{O}, \mathrm{H}_{2}, \mathrm{CO}$ and $\mathrm{CO}_{2}$ versus the space variable along the CFBMR (shell side zone). Figure (c) shows the evolution of the molar flow rates in the permeation side and shell side zones versus the time variable at the exit of the CFBMR. Figure (d) presents the evolutions of the molar flow rates of $\mathrm{H}_{2}$ at different temperatures $(1250 \mathrm{~K}, 1150 \mathrm{~K}$ and $950 \mathrm{~K})$ in the permeation side and shell side zones.

(a)

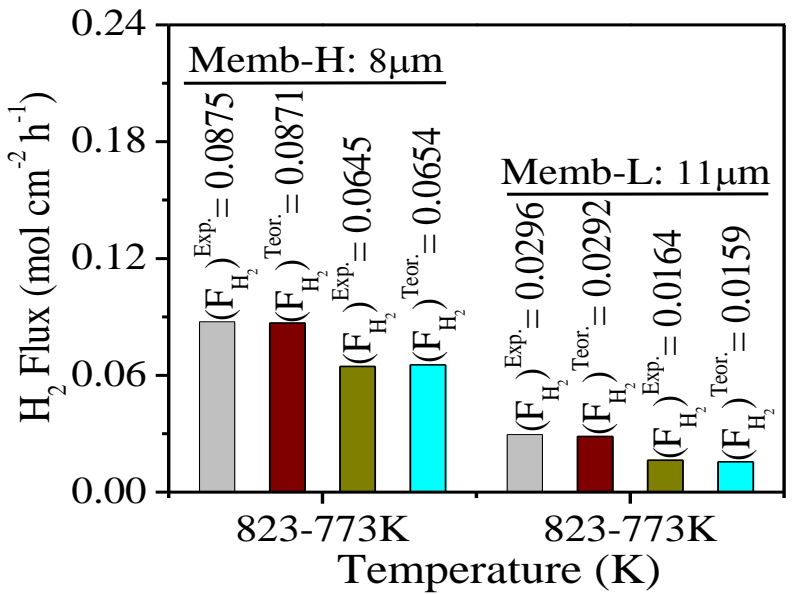

(c)

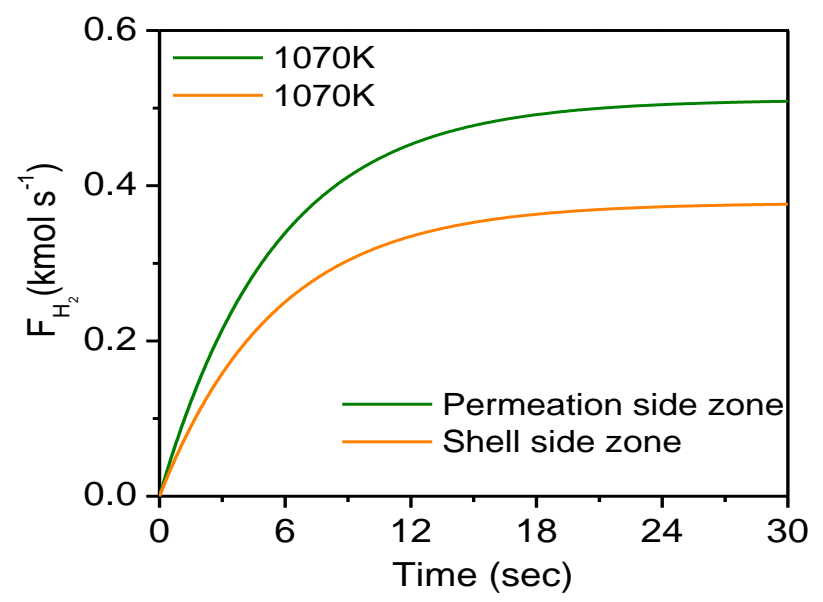

(b)

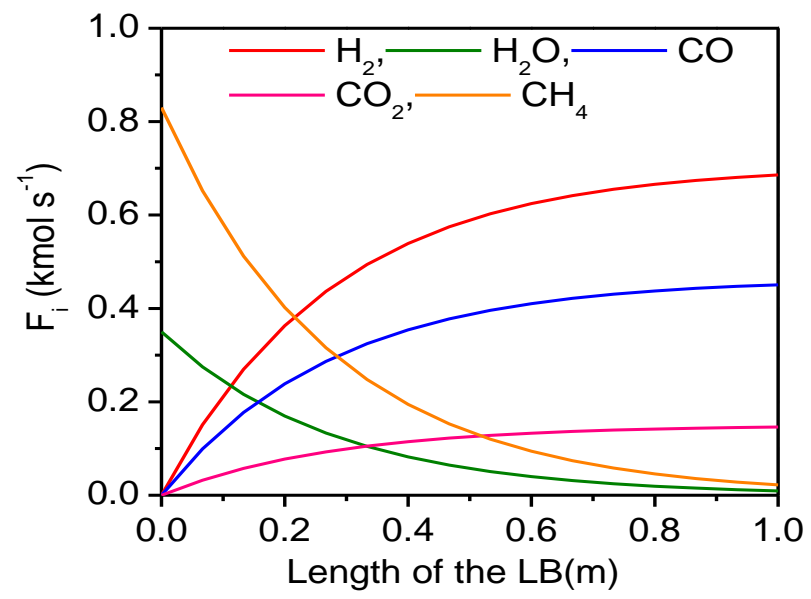

(d)

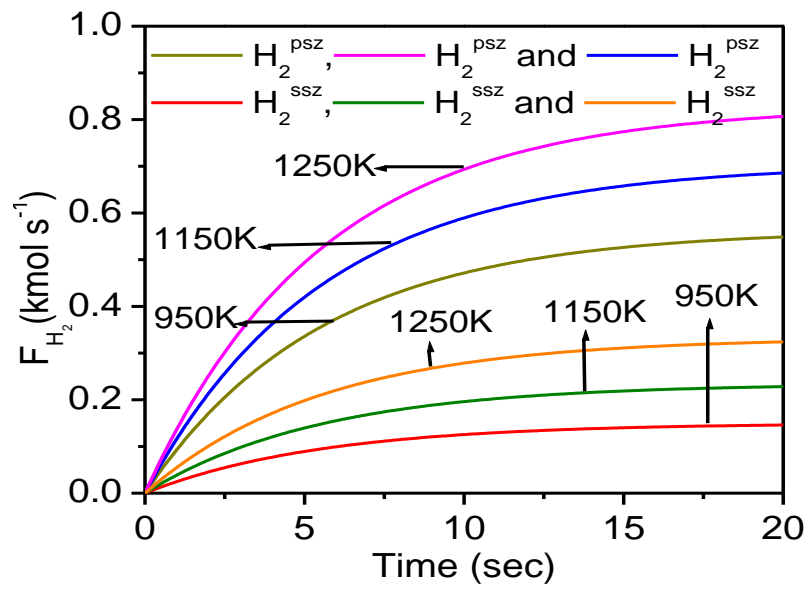

Figure 2: (a) Validation of the model, (b) Profiles of chemical species $\left(\mathrm{CH}_{4}, \mathrm{H}_{2} \mathrm{O}, \mathrm{H}_{2}, \mathrm{CO}\right.$ and $\mathrm{CO}_{2}$ ) along the CFBMR, (c) Evolutions of molar flow rates in the permeation side and shell side zones and (d) Evolutions of molar flow rates in the permeation side and shell side zones at different temperatures. 


\section{CONCLUSIONS}

Conducted in the context of reform of the line of chemical components, this research will resort numerical methodology in order to carry out the development process in isothermal catalytic membrane reactor dynamics of fixed bed. In conditions allowed for this research, the method of Runge-Kutta Gill was used to predict the model components $\left(\mathrm{CH}_{4}, \mathrm{H}_{2} \mathrm{O}, \mathrm{H}_{2}, \mathrm{CO}\right.$ and $\mathrm{CO}_{2}$ ). The development of computer code to process and analyze the behavior of the variables in this research allowed the lead the following conclusions:

- The validation confirmed by comparing which the results of this research and the results obtained by different authors are good agreement;

- Consumption and production have shown the profiles of chemical species $\left(\mathrm{CH}_{4}, \mathrm{H}_{2} \mathrm{O}, \mathrm{H}_{2}, \mathrm{CO}\right.$ and $\mathrm{CO}_{2}$ ) along the CFBMR;

- The molar flow rates of $\mathrm{H}_{2}$ at $1070 \mathrm{~K}$ shown a evolution with the time. Once, The amount of $\mathrm{H}_{2}$ is most in the permeation side zone than in the shell side zone;

- The molar flow rates of $\mathrm{H}_{2}$ at different temperatures $(1250 \mathrm{~K}, 1150 \mathrm{~K}$ and $950 \mathrm{~K}$ ) have shown a evolution with the time. Once, the amount of $\mathrm{H}_{2}$ is most in the permeation side zone than in the shell side zone.

\section{REFERENCES}

Abashar M. E. E., 2013, Steam reforming of n-heptane for production of hydrogen and syngas, International Journal of Hydrogen Energy, 38, 861-869.

Peijun J., Van Der Kooi H.J., De Swaan Arons J., 2003, Simulation and thermodynamic of an integrated process with $\mathrm{H}_{2}$ membrane CPO reactor for pure $\mathrm{H}_{2}$ production, Chemical Engineering Science,58, 3901-3911.

Keyur S.P., Aydin K.S., 2007, Modeling and simulation of methane steam reforming in a thermally coupled membrane reactor, International Journal of Hydrogen Energy, 32, 2344-2358

Oliveira C. C. B., Silva J. D., 2012, Dynamic modelling of the gasification region of a bubbling fluidized bed gasifier, Chemical Engineering Transactions, 29, 841-846. doi: 10.3303/CET1229141.

Pantoleontos G., Kikkinides, E. S., Georgiadis, M.C., 2012, A heterogeneous dynamic model for the simulation and optimisation of the steam methane reforming reactor, International Journal of Hydrogen Energy, 37, 16346 - 16358.

Silva J. D., Oliveira C. C. B., 2013, Mathematical modelling for the adsorption process $\mathrm{CO}_{2}$ in nanopores of catalytic particles in a fixed bed reactor using numeral Laplace transform, Chemical Engineering Transactions, 35, 829-835, doi: 10.3303/CET1335138.

Tong, J. and Matsumura, Y., 2006, Pure hydrogen production by methane seteam reforming with hydrogen-permeable membrane reactor, Catalysis Today, 111, 147-152.

Xu J, Froment G. F., 1989, Methane steam reforming, methanation and water-gas shift: I. Intrinsic kinetics, Aiche Journal, 35, 88-96. 